DOI 10.18551/rjoas.2019-11.22

\title{
WATER QUALITY ASSESSMENT IN SOME PONDS BY USING ALGAE IN ERBIL PROVINCE, NORTH IRAQ
}

\author{
Rabar Mohammed Hussein \\ Department of Basic Aquatic Sciences, Faculty of Fisheries, Fırat University, Elazig, Turkey \\ E-mail: rabarmohammad@yahoo.com
}

\begin{abstract}
The study was conducted in three ponds within Shanader Park, Erbil, and Kurdistan region north of Iraq. Water samples were collected in polyethylene bottles and algal samples were collected in sterile vial of $50 \mathrm{ml}$. physical, chemical and biological tests were include: air and water temperature, $\mathrm{pH}, \mathrm{EC}$, total hardness, calcium, and magnesium. On the other hand, biological tests include algal identification. The results indicate that water and air temperature were 9-10, $14-15^{\circ} \mathrm{C}, \mathrm{pH}$ 7.95- 8.11, EC between 359-392 (S/m). Total hardness between 174-202 mg/l CaCO3 l-1, Calcium hardness between 71- $84 \mathrm{mg} / \mathrm{l}$, Magnesium hardness between $24-28 \mathrm{mg} / \mathrm{l}$. The results of algal identification when recorded 11 genera include: Cladophora sp., Chloroccocum sp., phormidium sp., synedra sp, Euglena sp. Chlamydomonas sp., Osillatoria sp., Lyngbya sp., Cymbella sp, Gloeotrichia sp., and Chroococcus sp. Some of them have an important role in pollution.
\end{abstract}

\section{KEY WORDS}

Quality assessment, ponds, algae, Erbil, North Iraq.

Water covers $71 \%$ of the Earth's surface, mainly in sea and oceans, $(1.7 \%)$ in small portions of water occur as groundwater. Also in Antarctica and Greenland (1.7\%), on the other hand in the air as vapor, clouds, and precipitation $(0.001 \%)$ [1]. Water plays an important role in the global economy. About 70 percentages of the freshwater utilize by human for agriculture [2].

Quality of water is affected by human influences and natural. Geology, hydrological and climatic is the most important in natural influences, since these affect the quality and the quantity of water available. The effects of human activities on water quality varied in the degree to which they disrupt the ecosystem and/or restrict water utilize. Water pollution effected by human faces, for example, is attributable to a single source, but the reasons for this kind of pollution, is effects on water quality and the necessary corrective [3].

Aquatic ecosystem includes rivers, ponds and lakes are mostly affected by heavy metals and pollutant discharged in industrial effluents and represents a potential risk to the health of humans and ecosystems [4]. A pond could be a body of standing water. That is ordinary smaller than a lake. It's a main part of a river system also they may be somewhat isolated depressions. On the other hand includes shallow water, marsh and aquatic life [5].

Algae phylogenetically, is a diverse group of simple organisms that have chlorophyll-a as their main photosynthetic pigment and lack a sterile covering of cells around reproductive cells. Carry out oxygenic, such as eukaryotes and prokaryotes [6]. Algae are important ecologically because they occupy the base of the food chain in aquatic ecosystems and produce half of the $\mathrm{O}_{2}$ released into the atmosphere. In addition, algae are the main food source for zooplankton and crustacean larvae and some fish species [7]. The aim of the study is to determine the quality of water which might be available to meet the future need also identification algal flora and create a comprehensive baseline data for three ponds in Shanadar Water bodies and evaluate the health of three ponds in Shanadar using the most important physico-chemical properties of water pollution indicators.

The study was conducted in three ponds within Shandar Park located in Erbil City north Iraq. The governorate of Erbil is located in the northern Kurdistan region of Iraq (Fig1), an area with a semi-arid continental climate. The summer season (June-September) is hot and dry, while the winters are colder and wet. Rainfall is limited to the period between October 
and November, averaging $543 \mathrm{~mm}$ annually. The governorate is bordered by the converging Tigris and Little Zab rivers in the south, while the Zagros Mountain range forms the northeastern part of the area [8].

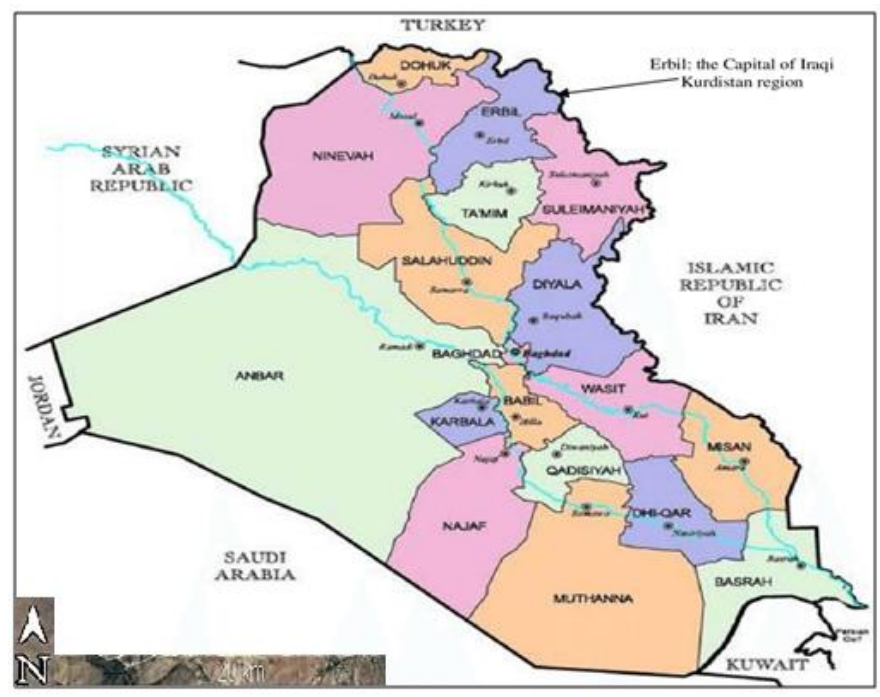

Figure 1 - Location of studied area (Iraq map) [9]

\section{MATERIALS AND METHODS OF RESEARCH}

Water samples from three different ponds were collected in winter season 2014. Surface water samples for physical, chemical and biological analysis. Physicochemical tests given in table 1 were including (Air temp, Water temp, EC, Total hardness, Calcium ion, Magnesium ion, $\mathrm{pH}$ ) were analyzed using standard methods described in [10].on the other hand algae samples from three different ponds were collected in clean plastic bottles also Compound microscope (Model E100) was used for algal identification depending on the following references[11-12].

\section{RESULTS AND DISCUSSION}

Physicochemical results (Table 1) in three ponds are given in the air temperature results ranged from $14-15^{\circ} \mathrm{C}$ on the other hand; Water temperature records for three ponds were ranged $8-9^{\circ} \mathrm{C}$. The $\mathrm{pH}$ scale is logarithmic and approximates the negative of the base 10 logarithm of the molar concentration (measured in units of molesper liter) of hydrogen ions in a solution. More precisely it is the negative of the base 10 logarithm of the activity of the hydrogen ion [13]. $\mathrm{pH}$ ranged was 7.95- 8.11. Electrical conductivity is the measure of the amount of electrical current a material can carry or its ability to carry a current. Electrical conductivity is also known as specific conductance. Conductivity is an intrinsic property of a material [14], it was measured as 359-392 (S/m). The principal natural sources of hardness in water are dissolved polyvalent metallic ions from sedimentary rocks, seepage and runoff from soils [15]. Hardness ranged were 174-202 mg/l CaCo $\mathrm{Ca}_{3}$. As mentioned above, a minor contribution to the total hardness of water is also made by other polyvalent ions, such as aluminium, barium, iron, manganese, strontium and zinc [15].

Table 1 - Physical and chemical results of the samples water

\begin{tabular}{|c|c|c|c|}
\hline Parameters & St1 & St2 & St3 \\
\hline Air Temp. ${ }^{\circ} \mathrm{C}$ & 15 & 14 & 15 \\
\hline Water Temp ${ }^{\circ} \mathrm{C}$ & 8 & 8 & 9 \\
\hline $\mathrm{PH}$ & 7.95 & 8.23 & 8.11 \\
\hline EC & 389 & 359 & 392 \\
\hline 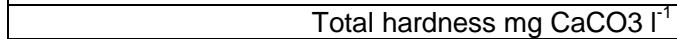 & 202 & 174 & 215 \\
\hline $\mathrm{Ca}^{+2} \mathrm{mg} / \mathrm{l}$ & 78 & 71 & 84 \\
\hline $\mathrm{Mg}^{+2} \mathrm{mg} / \mathrm{l}$ & 27 & 24 & 28 \\
\hline
\end{tabular}


Table 2 - Biological results of the sample

\begin{tabular}{|c|c|c|c|}
\hline Genus & St1 & St2 & St3 \\
\hline Chladophora sp. & & + & + \\
\hline Chloroccocum sp. & & & + \\
\hline Phormidium sp. & + & + & + \\
\hline Synedra sp. & & & + \\
\hline Euglena sp. & & & + \\
\hline Chlamydomonas sp. & + & & \\
\hline Osillatoria sp. & + & + & \\
\hline Lyngbya sp. & + & + & \\
\hline Cymbella sp. & + & & + \\
\hline Gloeotrichia sp. & + & & \\
\hline Chroococcus sp. & + & & \\
\hline
\end{tabular}

Table 3 - Some water quality parameters used for testing quality of water and their sources of and potential health effect [16]

\begin{tabular}{llll} 
Parameters & Sources & Potential health effects & \multicolumn{1}{c}{$\begin{array}{l}\text { Fresh water guideline, } \\
\text { mg/L }\end{array}$} \\
\hline $\mathrm{pH}$ & $\begin{array}{l}\text { Due to different dissolved } \\
\text { gases and solid }\end{array}$ & Bitter test, corrosion, affect mucus membrane & EDWQ, 20I0 \\
Temp. & $\begin{array}{l}\text { Due to chemical reaction, } \\
\text { hot waste water }\end{array}$ & $\begin{array}{l}\text { Influence chemical, biochemical, biological of aquatic } \\
\text { system, effect on solubility of essential gases }\end{array}$ & $6.5-8.5$ \\
EC & $\begin{array}{l}\text { Due to different dissolved } \\
\text { solid }\end{array}$ & High conductivity increases corrosive nature of water & -
\end{tabular}

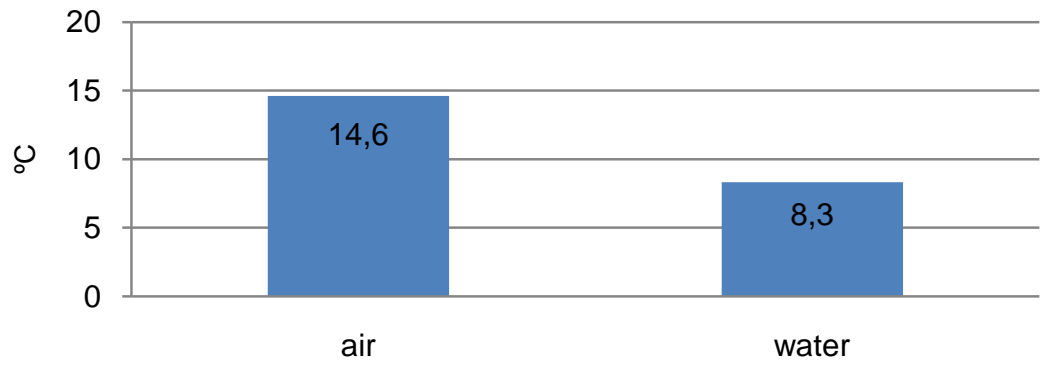

Figure 2 - Mean of Air and water temperature in three ponds of Erbil City

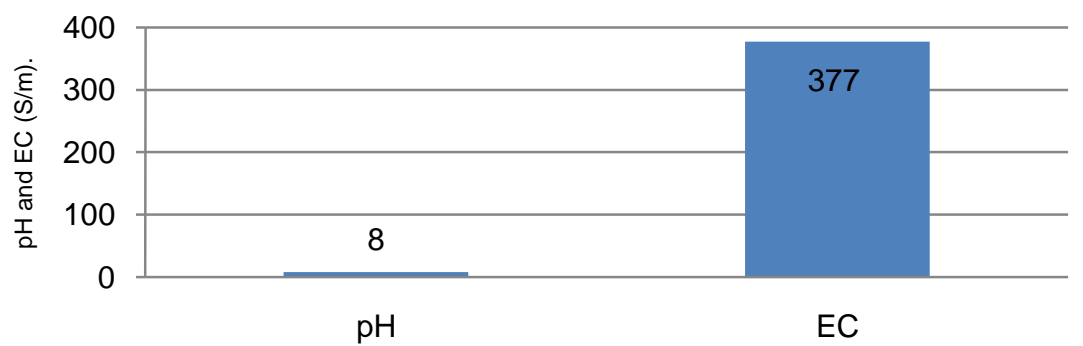

Figure 3 - Electrical conductivity and $\mathrm{pH}$ in three ponds of Erbil City

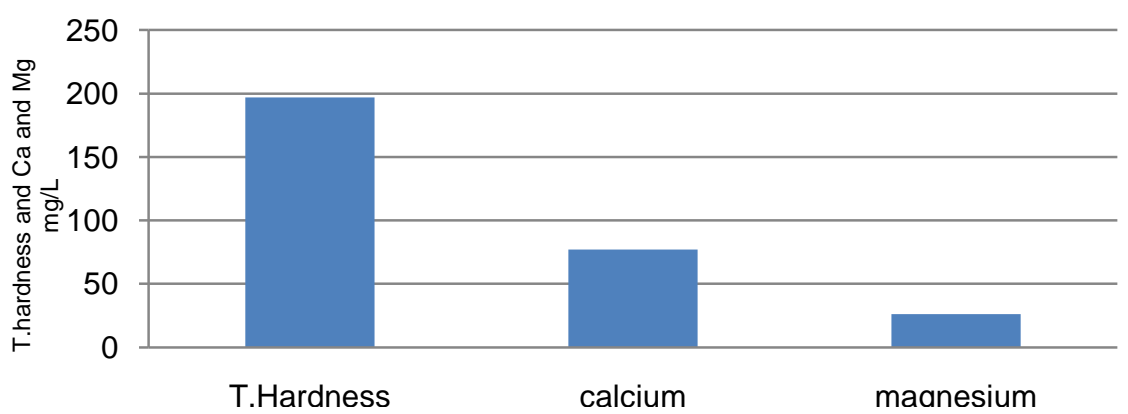

Figure 4 - Total hardness, calcium and magnesium in three ponds of Erbil City 
Calcium ranged were $71-84 \mathrm{mg} / \mathrm{l}$, magnesium ranged were $24-28 \mathrm{mg} / \mathrm{l}$. in point of algal samples were fresh photo were taken when even it need with microscope camera model (Olympus PM-b, Japana). Non-diatom algal forms were identified the genus depending on the following references flora [11-12]. With tributaries revealed that we identified 11 algal genus some of them have an indicator of pollution.

\section{CONCLUSION}

Generally, water temperature never fall below $8^{\circ} \mathrm{C}$ and it was noted during the study period. Calcium ion concentrations were higher than magnesium ion concentration. Electrical conductivity values were high showing that in three ponds are rich in ions. Identified 11 different kinds of algae genus some of them have an important role of a pollution. Maintenance of distribution system and methods must be planned, implemented and operation- protection of the treatments must be undertaken by the authority control [17].

\section{REFERENCES}

1. Gleick, P.H., ed. Water in Crisis: A Guide to the World's Freshwater Resources. Oxford University Press. p. 13, Table 2.1 "Water reserves on the Earth". Archived from the original on 8 April, 2013.

2. Baroni, L.; Cenci, L.; Tettamanti, M.; Berati, M. "Evaluating the environmental impact of various dietary patterns combined with different food production systems". European Journal of Clinical Nutrition. 61 (2): 279-286, 2007. doi:10.1038/sj.ejcn.1602522. PMID 1703595.

3. WHO. Water Quality Monitoring - A Practical Guide to the Design and Implementation of Freshwater Quality Studies and Monitoring Programmes. 1996.

4. Priscila O. Souza et.I. Algae of economic importance that accumulate cadmium and lead: A review. Revista Brasileira de Farmacognosia Brazilian Journal of Pharmacognosy, 22(4): 825-837, Jul./Aug.2012.

5. John Clegg. The New Observer's Book of Pond Life. Frederick Warne, London. pp. 460. 1986.

6. Edward G. B and David C. S. Freshwater Algae: Identification and Use as Bioindicators. John Wiley \& Sons, Ltd, pp. 245, 2010.

7. Cardozo, 2007. Metabolites from algae with economical impact. Comparative Biochemistry and Physiology Part C Toxicology \& Pharmacology, 146(1-2):60-78.

8. NCCl. www.ncciraq.org/images/infobygov/NCCl_Erbil_Governorate_Profile.pdf 2015.

9. Hussein et al, 2019. Phycolimnological Study on Water Bodies of Two Major Parks in Erbil Province (North Iraq). Fresenius Environmental Bulletin.

10. APHA (2012) "Standard methods for the examination of water and wastewater", (Eugene W. R., Rodger B. B., Andrew D. E., Lenore S. C.): American Public Health Association, American Water Works Association, Water Environment Federation.

11. Prescott, G., 1968. Algae of the Western Great Lakes Area. W. C. Brown Co, the United States of America.

12. Bold, H., \& Wynne, M. Introduction to the algae: structure and reproduction, (2nd ed.): Princeton, New Jersey: Prentice Hall. 1985.

13. Bates, Roger G. Determination of $\mathrm{pH}$ : theory and practice. Wiley, 1973.

14. Anne Marie, 2018. www.thoughtco.com/definition-of-electrical-conductivity-605064.

15. WHO, "Guidelines for Drinking-Water Quality", Health Criteria and Other Supporting Information (2nd Ed. Vol. 2): World Health Organization. Geneva. 1996.

16. U.S. EPA, Draft Guidance on the Use of Models and Other Analyses in Attainment Demonstrations for the 8-Hour Ozone NAAQS, EPA-454/R-99-004, 1999.

17. Rabar Mohammed Hussein, Bulent Sen, Mustafa Koyun, and Ali Riza Demirkiran. (2019). "Effects Of Storage Temperature and Sun Light Exposure on Some Bottled Water Marketed in Kirkuk City, North Iraq". International Journal of Engineering Technologies and Management Research, 6(7), 16-26. DOI: 10.5281/zenodo.3341452. 